\title{
Opinion on a new and Challenging Tool in Prenatal Counseling: Non invasive Prenatal Testing by Fetal Cell-Free DNA in Maternal Blood
}

\section{Justo Alonso*}

Department of Obstetrics and Gynecology, Facultad de Medicina de Montevideo, Universidad de la Republica Oriental del Uruguay, Uruguay

\begin{abstract}
Practicing obstetricians are constantly facing new challenges regarding prenatal diagnosis, as knowledge on this field increases exponentially. Continuous medical education in this area as in others is essential for a good clinical practice and appropriate counseling to patients
\end{abstract}

\section{Introduction}

Congenital defects are currently the leading cause of infant mortality in the developed world. The reported prevalence of congenital defects ranges from as low as 4 per one hundred live births in France, to over 8 per hundred live births in Sudan. Worldwide, this figure is 6 per hundred live births on average [1].

In developed countries, chromosomal disorders cause one out of ten congenital defects; which means that 9 out of ten babies born with a major defect will have a normal karyotype [2]. Nevertheless, fetal karyotype analysis is an important component of prenatal diagnosis, as some entities (for example Down's syndrome) may not be adequately diagnosed by ultrasound examination biochemical screening, or a combination of both (triple screening at 11-14 weeks, quadruple screening in second trimester).

Prenatal Medicine has witnessed some major advances in the last two decades. Ultrasound imaging is the most groundbreaking among them and, to this date also the most useful tool for prenatal diagnosis.

Prenatal prevalence of chromosomal anomalies, according to Wellesley et al. [3] has the following distribution:

1. Trisomy 21: $53 \%$

2. Trisomy $18: 13 \%$

3. Trisomy $13: 5 \%$

4. 5 X0 (Turner): $8 \%$

5. Sex trisomy: $5 \%$

6. Other rare: $16 \%$

Both ultrasound and biochemical screening are non-invasive and present no risk to the fetus, although the former strongly depends on the expertise of the technician performing the study.

On the other hand, before 2012DNA analysis of fetal cells required invasive techniques to obtain fetal or placental cells (amniocentesis or chorionic villus sampling - CVS).These procedures were costly and required considerable expertise, while at the same time presenting the risk of abortion and only providing small amounts of fetal chromosomes [4].

These techniques carried an abortion risk of 1 in 300 for amniocentesis and 1 in 250 for CVS, and were therefore only offered to women whose risk of karyotype alterations surpassed the risk of such an invasive procedure [5].

2012 saw a turning point in prenatal chromosome analysis due to the development of appropriate methods for studying cell-free fetal DNA in maternal blood by massive sequencing technologies.
This paper presents a review of the new diagnostic methods available for the most frequent aneuploidies (mainly Massive Sequencing of fetal cell-free DNA), and explains the implications for everyday pregnancy control of the practicing obstetrician. These technologies add challenges to our daily practice.

\section{Classical Karyotype Analysis}

Presently, a complete karyotype of the fetus can only be obtained by one of three methods, all of them requiring complete fetal cells nuclei

\section{Chorionic villus sampling (CVS)}

CVS is ideally performed at 12 weeks of gestation. Guided by ultrasound, an appropriate needle is inserted in the placenta to obtain a small amount of chorionic villus tissue. The cells of this tissue usually carry the same DNA as somatic cells, except in rare cases of mosaicism $[6,7]$.

Among experienced professionals, the rate of complications (mainly abortion) of this invasive technique is 1 per 200-250 CVS [8].

Chorionic villi need to be washed and separated from maternal tissue (decidua and maternal blood), fetal cells are identified and their karyotype is analyzed. Results are obtained in a few days, usually less than a week. Abnormal results must be confirmed through an amniocentesis because of the chance of mosaics.

CVS has a99.25\% sensitivityfor aneuploidy detection with a specificity of $98.65 \%$ [4].

\section{Amniocentesis}

This technique obtains amniotic fluid through an ultrasound guided needle. It can be performed after 13-14 weeks of gestation. Requiring the culture of fetal fibroblasts, Amniocentesis enables the analysis of the fetal karyotype. It'srate of complications (mainly abortion) among

*Corresponding author: Dr. Justo Alonso, Professor and Chairman, Department of Obstetrics and Gynecology, Facultad de Medicina de Montevideo, Universidad de la Republica Oriental del Uruguay, Uruguay, Tel: 59827087900 ; E-mail: alonso.justo@gmail.com

Received November 06, 2013; Accepted November 19, 2013; Published November 25, 2013

Citation: Alonso J (2013) Opinion on a new and Challenging Tool in Prenata Counseling: Non invasive Prenatal Testing by Fetal Cell-Free DNA in Maternal Blood. J Health Med Informat 4: 138. doi:10.4172/2157-7420.1000138

Copyright: (c) 2013 Alonso J. This is an open-access article distributed under the terms of the Creative Commons Attribution License, which permits unrestricted use, distribution, and reproduction in any medium, provided the original author and source are credited. 
Citation: Alonso J (2013) Opinion on a new and Challenging Tool in Prenatal Counseling: Non invasive Prenatal Testing by Fetal Cell-Free DNA in Maternal Blood. J Health Med Informat 4: 138. doi:10.4172/2157-7420.1000138

Page 2 of 5

experienced professionals is 1 per 300 procedures [5].

Culture of enough fetal cells to obtain adequate amounts of chromosomes to produce a reliable report usually requires two weeks. Amniocentesis has a $99.4 \%$ sensitivity for aneuploidy detection, with a specificity of $99.5 \%$ [9].

\section{Fetal cells from maternal blood}

As early as 1954, Chown [10] detected fetal bleeding to the maternal circulation. In 1969, fetal lymphocytes were detected and isolated from maternal blood [11]. Several fetal cell types carrying fetal genome have been reported to exist in the maternal circulation. These include fetal trophoblasts, lymphocytes, granulocytes and nucleated erythrocytes.

Since 1990 several efforts have been successful in obtaining fetal cells from maternal blood. All procedures developed for sorting fetal from maternal cells are complex and expensive, since the ratio of fetal to maternal cells in pregnancy is about 1 in 1,000. Despite some promising early results with fluorescent in situ hybridization (FISH), the reproducibility and reliability of these techniques are still limited, mainly due to the lack of very specific cell markers and the very low and variable concentrations of fetal cells among numerous maternal cells [12].

These techniques have not gained wide acceptance, mainly for the former reasons, but also because of high costs.

These three techniques can render results earlier if "chromosome painting" [13] procedures are used, consisting of specific fluorescent antibodies that target the desired chromosomes (usually the most frequently involved in trisomies.

\section{Combined ultrasound/biochemical screening for fetal aneuploidies}

In the 1980's, abnormally high values of maternal serum AlphaFeto-Protein (AFP) were linked to neural tube defects [14]. In the same decade, a series of fetal or placental proteins were also demonstrated to correlate with Down's syndrome and other frequent trisomies: HCGbeta (Beta fraction of Human Chorionic Gonadotrophin), Estriol and PAPPA (Pregnancy Associated Plasma Protein A) [15,16].

In association with ultrasound markers (Nuchal Translucency, nasal bone, ductusvenosus flow measured by Doppler ultrasound), these screening tools were developed to determine the risk of aneuploidies $[17,18]$. These procedures have received unanimous acceptance from obstetricians and patients for being low-cost and risk-free, becoming mainstream worldwide. These techniques, however, do not have diagnostic value, their results expressing probability, not certainty. For example, detection rates for aneuploidies of Down's syndrome by these combined techniques (Triple or Quadruple screening) range from 60 to $80 \%[19,20]$.

Results of these screening tests therefore yield only risk estimates for aneuploidies. A negative result (low risk) could be misinterpreted as determining that the fetus is normal, while a positive screening test, based on high risk, may lead to unnecessary invasive procedures.

After an abnormal result of a screening test an invasive procedure should be offered.

\section{Limitations of Current Aneuploidy Testing}

\footnotetext{
- High false positive rate (5\%)

- Late information
}

\author{
- Prolongs uncertainty \\ - Involves multiple visits \\ - Requires specialized ultrasound \\ - Safety concerns (CVS and amniocentesis)
}

\section{Cell-free fetal DNA in maternal blood}

Simpson and Elias were able to demonstrate in 1993 that fetal cell free DNA (cfDNA) fragments were present in maternal blood [21]. In 1997 Lo et al. first isolated fragments of fetal DNA in maternal serum and plasma [22], and Fan et al. applied massive sequencing to diagnose targeted fetal aneuploidies from maternal blood in 2008 [23]. A cascade of new studies soon followed, supporting the viability of the isolation and analysis of cell free fetal DNA from maternal blood [24-29] to diagnose chromosomal anomalies.

To this end, two types of fetal DNA can be isolated from maternal blood: the one present in the nuclei of fetal cells (one in 1,000 million cells in maternal circulation), or cell-free fragments of DNA (2 to $20 \%$ of total cell-free DNA in maternal circulation [26]

Fetal DNA is released by apoptosis into maternal blood as small fragments of 150-200 pairs of bases. Thus, maternal blood contains both maternal and fetal cell-free DNA, which can be detected as soon as 7 weeks into gestation and becomes undetectable 2 hours after delivery [28].

This paper does not attempt to describe the methodology of DNA sequencing and will focus mainly on the clinical implications of the Non Invasive Prenatal Testing (NIPT) of the most frequent aneuploidies.

\section{Importance of fetal fraction}

The fraction of fetal DNA should be above $10 \%$ of all cfDNA in maternal circulation in order for this technique to render significant results. Since, fractions below $10 \%$ can lead to erroneous interpretations [24], in these cases most laboratories offering the technique opt instead to obtain a redraw of maternal blood to perform a correct analysis [30].

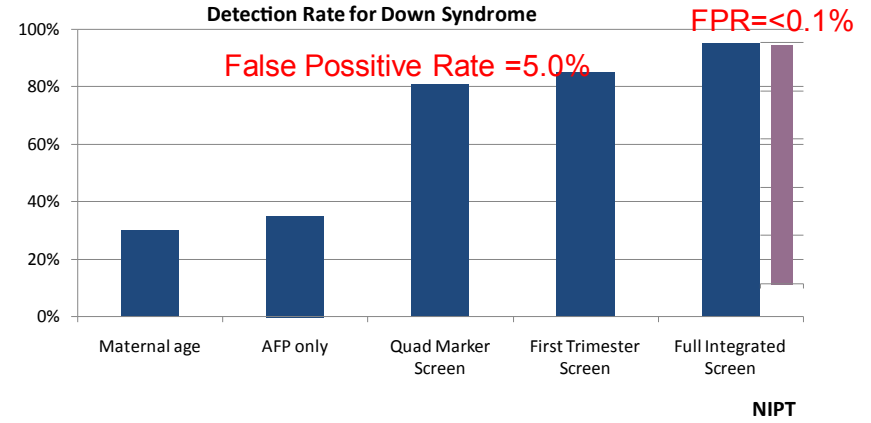

Figure 1: Evolution of trisomy assessment.

\begin{tabular}{|l|l|l|l|l|l|}
\hline \multicolumn{6}{|l|}{ Rates based on published data } \\
\hline Reference \# & T21 & T18 & T13 & 45X & XXX/XXY \\
\hline 31 & $99.9 \%$ & $99.9 \%$ & $99.9 \%$ & $99.9 \%$ & $99.9 \%$ \\
\hline 32 & $\begin{array}{l}98.6 \%- \\
99.1 \%\end{array}$ & $100 \%$ & $91.7 \%$ & N/A & N/A \\
\hline 33 & $100 \%$ & $97.2 \%$ & $78.6 \%$ & $93.8 \%$ & N/A \\
\hline 34 & $100 \%$ & $98.0 \%$ & N/A & N/A & N/A \\
\hline
\end{tabular}

Table 1: Detection rates. 


\begin{tabular}{|c|c|c|c|c|}
\hline & $\begin{array}{l}\text { Natera } \\
\text { Panorama }\end{array}$ & $\begin{array}{l}\text { Verinata } \\
\text { Verifi }\end{array}$ & $\begin{array}{l}\text { Sequenom MaterniT21 } \\
\text { PLUS }\end{array}$ & $\begin{array}{l}\text { Ariosa } \\
\text { Harmony }\end{array}$ \\
\hline Identified Trisomies & $13,18,21$ & $13,18,21$, sex chromosomes & $\begin{array}{l}13,18,21, \text { sex } \\
\text { chromosomes }\end{array}$ & $\begin{array}{l}13,18,21, \text { sex } \\
\text { chromosomes }\end{array}$ \\
\hline Identified Monosomies & X Chromosome & X Chromosome & X Chromosome & X Chromosome \\
\hline Method & Single Nucleotid Polymorphism & Massive Parallel Sequencing & $\begin{array}{l}\text { Massive Parallel } \\
\text { Sequencing }\end{array}$ & Selective Sequencing \\
\hline Sensitivity & $92-99 \%$ & $87-99 \%$ & $92-99 \%$ & $80-99 \%$ \\
\hline Specificity & $100 \%$ & $100 \%$ & $>99 \%$ & $>99 \%$ \\
\hline \multicolumn{5}{|l|}{ Earlier } \\
\hline gestational age & $9 w$ & $10 w$ & $10 w$ & $10 w$ \\
\hline
\end{tabular}

Table 2: NIPT is not diagnostic, since it can render false positive results.

\begin{tabular}{|l|l|l|}
\hline & Detection rate & FPR \\
\hline Trisomy 21 & $590 / 594(99.5 \%)$ & $0.1 \%$ \\
\hline Trisomy 18 & $222 / 230(97 \%)$ & $0.1 \%$ \\
\hline Trisomy 13 & $30 / 38(79 \%)$ & $0.1 \%$ \\
\hline
\end{tabular}

cfDNA does not always correlate with fetal genotype (placental mosaicism, vanishing twin, maternal mosaicism)

Table 3: NIPT Performance-All cfDNA Methods.

NIPT results need to be taken in the context of disease prevalence Example:

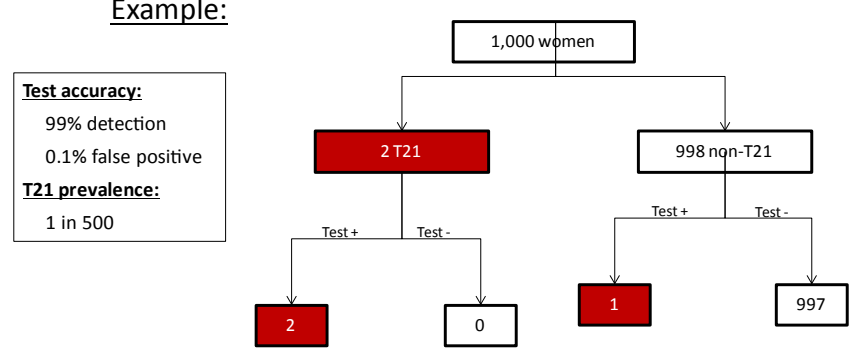

Figure 2: NIPT for T21-Not Diagnostic. Screening Courtesy of Dr. Thomas Musci, Ariosa Diagnostics.

\section{The role of placental mosaicism}

As cfDNA originates from placenta, most likely from the trophoblast, it can be likened to the direct preparation of chorionic villi. It must be noted that the chromosomal makeup of the placenta and fetus can be different, a situation occurring more frequently with chromosomes 13 and 18, as compared to chromosome 21. This can lead to false positive and false negative results [7].

\section{Clinical implications}

To this day, only five laboratories worldwide are capable of performing and commercializing the sequencing technique for cellfree fetal DNA in maternal blood. Four of them are established in California, USA (in brackets: the registered trade mark for each of the tests offered): Verinata (Verifi), Natera (Panorama), Ariosa (Harmony), and Sequenom (MaternitiT21); and one in China: BGI.

Results of the different tests offered are very similar in both sensitivity and specificity to diagnose T21, T18, T13 and sexual chromosomes aneuploidies (Tables 1-3).

It is quite clear that these are multi-million dollar operations, since the foreseeable future will certainly bring a rapid increase in the number of women seeking this non-invasive test. To date, the only way to perform these tests on maternal blood requires that the samples be air-mailed to one of these few patent-holding laboratories in the USA.
If a definitive diagnosis is desired, invasive procedures are required to confirm a positive non-invasive prenatal testing (NIPT) result. Test results should always be interpreted in the context of all available clinical findings. It is recommended that the healthcare provider determines the utilization of the test, including the need for genetic counseling.

NIPT is not diagnostic, since it can render false positive results (Figures 1 and 2).

There are plenty of recent publications on this subject, and a number of on-going studies that reinforce the technique's value (Table 4).

The most ambitious of these projects is the NICE study [31] (Table 5) that enrolled 50 participating clinical sites in the U.S.A. and Europe, yielding a sensitivity of $100 \%$ and a specificity of $99.97 \%$ for Down syndrome, with a false positive rate of only $0.03 \%$.

At this point, the Committee Opinion of the ACOG (the American Congress of Obstericians and Gynecologists) must be presented [32].

"Cell free fetal DNA appears to be the most effective screening test for aneuploidy in high risk women... is one option that can be used as a primary screening test in women at increased risk of aneuploidy". "[NIPT] should be an informed patient choice after pretest counseling". "[NIPT] should not be offered to low-risk women or women with multiple gestations". "A patient with a positive test result should be referred for genetic counseling and should be offered invasive prenatal diagnosis for confirmation of test results." This opinion on NIPT can be summarized in 6 points:

* NIPT should be an informed patient choice

${ }^{\star}$ It should not be part of routine prenatal laboratory assessments

* Low-risk women or women with multiple gestations should not be offered NIPT

* A negative test does not ensure an unaffected pregnancy

* A patient with a positive test result should be referred to genetic counseling

* Invasive prenatal diagnosis should be offered for confirmation of a positive NIPT result

Different situations leading to false positive results can be linked to abnormal cfDNA circulating in maternal blood from a source from the fetus, as might be the case of a woman with cancer, as recently reported by Osborne at the American College of Medical Genetics and Genomics annual Clinical Genetics Meeting in March 2013 [33]. In this report he describes a false NIPT diagnosis of both trisomies 13 
Citation: Alonso J (2013) Opinion on a new and Challenging Tool in Prenatal Counseling: Non invasive Prenatal Testing by Fetal Cell-Free DNA in Maternal Blood. J Health Med Informat 4: 138. doi:10.4172/2157-7420.1000138

Page 4 of 5

\begin{tabular}{|c|c|c|}
\hline Study & Status & Description \\
\hline $\begin{array}{l}\text { NICE } \\
\text { (Non-Invasive Chromosomal Evaluation) }\end{array}$ & $\begin{array}{l}\text { Published-Editor's choice in The Gray Journal (August } \\
\text { 2012) }\end{array}$ & $\begin{array}{l}\text { Multi-center ( } 50 \text { sites) clinical validation study, combined high risk and } \\
\text { low risk women. Largest NIPT cohort study. }\end{array}$ \\
\hline Average Risk (Nicolaides) & Published-The Gray Journal (2012, avail online) & Exclusive average risk study of Harmony test in $1^{\text {st }}$ trimester pregnancy \\
\hline Ariosa Blinded & $\begin{array}{l}\text { Published-Editor's choice in The Gray Journal (April } \\
\text { 2012) }\end{array}$ & Blinded study with risk score reporting \\
\hline Nicolaides Blinded & $\begin{array}{l}\text { Published-Editor's choice in The Gray Journal (April } \\
\text { 2012) }\end{array}$ & $1^{\text {st }}$ trimester blinded study \\
\hline Proof of Concept & Published-cover article Prenatal Diagnosis (Jan 2012) & $\begin{array}{l}\text { Initial description of directed cfDNA approach with combined average } \\
\text { risk and high risk women }\end{array}$ \\
\hline Trisomy 13 & Published-The White Journal (Jan 2013) & $\begin{array}{l}\text { Performance for } \mathrm{T} 13 \text { detection with combined average risk and high } \\
\text { risk women }\end{array}$ \\
\hline Fetal Fraction-NICE substudy & Published-J Mat Fet Med (Jan 2013) & Fetal fraction same in high and low risk women \\
\hline Fetal Fraction & Published-Fetal Diagnosis and Therapy (2012) & Fetal fraction correlated to placental mass \\
\hline $\begin{array}{l}\text { NITE } \\
\text { (Non-Invasive Trisomy Evaluation) }\end{array}$ & Completed and under review & Multi-center European blinded study \\
\hline $\begin{array}{l}\text { NEXT } \\
\text { (Non-invasive EXamination of Trisomy) }\end{array}$ & Enrolling & $\begin{array}{l}\text { Multi-center blinded study of average risk women comparing Harmony } \\
\text { to } 1^{\text {st }} \text { trimester combined screening }\end{array}$ \\
\hline
\end{tabular}

Table 4: Clinical Studies \& Publication Overview.

\begin{tabular}{|l|l|l|l|}
\hline & Sensitivity & Specificity & False Positive Rate \\
\hline Trisomy 21 & $100 \%$ & $99.97 \%$ & $0.03 \%$ \\
& $(81 / 81)$ & $(2887 / 2888)$ & $(1 / 2888)$ \\
\hline Trisomy 18 & $97 \%$ & $99.93 \%$ & $0.07 \%$ \\
& $(37 / 38)$ & $(2886 / 2888)$ & $(2 / 2888)$ \\
\hline
\end{tabular}

NICE Study Overview

*50 participating clinical sites in U.S. and Europe

* Largest cohort study to date-All eligible subjects evaluated

*Study population was women undergoing invasive testing for any indication and

thus included low risk women

Table 5: Showing the NICE Study Overview.

and 18 , with a normal ultrasound. "Amniocentesis was performed and interphase FISH for common aneuploidies, fetal karyotype, and SNP (Single Nucleotid Polimorphysm) microarray analysis were reported as normal. After full term vaginal delivery of a clinically normal, nondysmorphic male, the patient was evaluated for persistent hip pain. She was subsequently diagnosed with metastatic small cell carcinoma of vaginal or cervical origin".

In this same annual clinical genetics meeting, two false negatives were reported by Dr. Rachel Allen from Lescale Maternal Fetal Medicine in New York State University. Both cases presented abnormal ultrasound scans and fetal karyotype was a trisomy 21 in both cases.

In conclusion, these are the reasons why we still need to be very cautious when counseling our pregnant parents on prenatal diagnosis. NIPT is clearly not a diagnostic tool. It should be called Non Invasive Prenatal Screening (NIPS) and should be used in association with the available diagnostic armamentarium, favoring non-invasive techniques when possible. Counseling should be provided in a fashion that best suits each individual patient or couple, with a strictly personalized clinical approach. Patient autonomy must always rule over the physician's acts, under a virtue-based ethic.

\section{Conclusions}

Practicing obstetricians face a new era of prenatal diagnosis and counseling. Techniques evolve rapidly and continuous medical education is indispensable for physicians to stay up-to-date in their daily practice.

Non Invasive Prenatal Screening appears as a promising method with proven benefits over other screening tools. It must be used with a thorough knowledge of the limitations of the technique and without disregarding time-tested screening and diagnostic tools.

A personalized approach must be sought for with each patient, and informed consent must be obtained in each case. Direct interviews must be held before deciding to perform the test and it is mandatory that the results are delivered personally by a geneticist or a specialist in perinatal medicine in order to answer all possible questions regarding the test's significance.

\section{References}

1. March of Dimes Global Report on birth defects (2006) Global Program, White Plains, New York,

2. ChristiansonAL, Howson CP, Modell B (2006) The March of Dimes Global Report on Birth Defects: The Hidden Toll of Dying and Disabled Children. New York: March of Dimes Birth Defects Foundation.

3. Wellesley D,Dolk H, Boyd PA, Greenlees R, Haeusler M, et al. (2012) Rarechromosome abnormalities, prevalence and prenatal diagnosis rates from population-basedcongenital anomaly registers in Europe. Eur J of Hum Gen 20: 521-526.

4. Hahnemann JM, Vejerslev LO (1997) Accuracy of cytogenetic findings on chorionic villus sampling (CVS)--diagnostic consequences of CVS mosaicism and non-mosaic discrepancy in centers contributing to EUCROMIC 1986-1992. Prenat Diagn 17: 801-820.

5. Mid-trimester amniocentesis for prenatal diagnosis. Safety and accuracy (1976) JAMA 236: 1471-1476.

6. Wirtz A, Gloning K, Murken J (1991) Trisomy 18 in chorionic villus sampling Problems and consequences. Prenat Diagn 11: 563-567.

7. Kalousek DK, Vekemans M (1996) Confined placental mosaicism. J Med Genet 33: 529-533.

8. Brun JL, Mangione R, Gangbo F, Guyon F, Taine L, et al. (2003) Feasibility, accuracy and safety of chorionic villus sampling: a report of 10741 cases. Prenat Diagn 23: 295-301.

9. Alfirevic Z, Sundberg K, Brigham S (2009) Amniocentesis and chorionic villus sampling for prenatal diagnosis. Cochrane Database Syst Rev Published by John Wiley \& Sons, Ltd.

10. Chown B (1954) Anaemia from bleeding of the fetus into the mother's circulation. Lancet. 2: 1213-1215.

11. Walknowska J, Conte FA, Grumbach MM (1969) Practical and theoretical implications of fetal-maternal lymphocyte transfer. Lancet 293: 1119-1122.

12. Holzgreve W, Garritsen HS, Ganshirt-Ahlert D (1992) Fetal cells in the maternal circulation. J Reprod Med 37: 410-418.

13. Sharma AK, Sharma A (2001) Chromosome painting-principles, strategies and scope. Methods Cell Sci 23: 1-5.

14. Wald NJ, Cuckle H, Brock JH, Peto R, Polani PE, et al. (1977) Maternal serumalpha-fetoprotein measurement in antenatal screening for anencephaly and 
Citation: Alonso J (2013) Opinion on a new and Challenging Tool in Prenatal Counseling: Non invasive Prenatal Testing by Fetal Cell-Free DNA in Maternal Blood. J Health Med Informat 4: 138. doi:10.4172/2157-7420.1000138

Page 5 of 5

spina bifida in early pregnancy. Report of U.K. collaborative study on alphafetoprotein in relation to neural-tube defects. Lancet 25: 1323-1332.

15. Cucklea HS, Walda N, Lindenbaumb R (1984) Maternal serum alpha-fetoprotein measurement: a screening test for Down syndrome. The Lancet 323: 926-929.

16. Haddow JE, Palomaki GE, Knight, GJ, Williams J, Pulkkinen A, et al. (1992) Prenatal screening for Down's syndrome with use of maternal serum markers. N Engl J Med 327: 588-593.

17. Spencer K, Souter V, Tul N, Snijders R, Nicolaides KH (1999) A screening program for trisomy 21 at 10-14 weeks using fetal nuchal translucency, maternal serum free $\beta$-human chorionic gonadotropin and pregnancy-associated plasma protein-A. Ultrasound Obstet Gynecol 13: 231-237.

18. de Graaf IM, Pajkrt E, Bilardo CM, Leschot NJ, Cuckle HS, et al. (1999) Early pregnancy screening for fetal aneuploidy with serum markers and nuchal translucency. Prenatdiagn19: 458-462.

19. Cicero S, Bindra R, Rembouskos G, Spencer K, Nicolaides KH (2003) Integrated ultrasound and biochemical screening for trisomy 21 using fetal nuchal translucency, absent fetal nasal bone, free $\beta$-hCG and PAPP-A at 11 to 14 weeks. Prenatal diagn 23: 306-310.

20. SchuchterK, Hafner E, StangI G, Ogris E, Philipp K (2001) Sequential screening for trisomy 21 by nuchal translucency measurement in the first trimester and maternal serum biochemistry in the second trimester in a low-risk population. Ultrasound Obstet Gynecol 18: 23-25.

21. Simpson JL, Elias S (1993) Isolating fetal cells from maternal blood. JAMA 270: 2357-2361.

22. Lo YM, Corbetta N, Chamberlain PF, RaiV, Sargent IL, et al. (1997) Presence of fetal DNA in maternal plasma and serum. lancet 350: 485-487.

23. Fan HC, Blumenfeld YJ, Chitkara U, Hudgins L, Quake SR (2008) Noninvasive diagnosis of fetal aneuploidy by shotgun sequencing DNA from maternal blood. Proc Natl Acad Sci U S A 105: 16266-16271.

24. Palomaki GE, Kloza EM, Lambert-Messerlian GM, Haddow JE, Neveux LM, et al. (2011) DNA sequencing of maternal plasma to detect Down syndrome: an international clinical validation study. Genet Med 13: 913-920.

25. Pertl B, Bianchi DW (2001) Fetal DNA in maternal plasma: emerging clinical applications. Obstet Gynecol 98: 483-490.

26. Bianchi DW, Platt LD, Goldberg JD, Abuhamad AZ, Sehnert AJ, et al. (2012) Genome-wide fetal aneuploidy detection by maternal plasma DNA sequencing. Obstet Gynecol 119: 890-901.

27. Chiu RW, Chan KA, Gao Y, Lau VY, Zheng W, et al. (2008) Noninvasive prenatal diagnosis of fetal chromosomal aneuploidy by massively paralle genomic sequencing of DNA in maternal plasma. Proceedings of the National Academy of Sciences 105: 20458-20463.

28. Goldberg JD (1997) Fetal cells in maternal circulation: progress in analysis of a rare event. Am J Hum Genet 61: 806-809.

29. Fan HC, Blumenfeld YJ, Chitkara U, Hudgins L, Quake SR (2010) Analysis of the size distributions of fetal and maternal cell-free DNA by paired-end sequencing. Clinchem 56: 1279-1286.

30. Chiu RW, Akolekar R, Zheng YW, Leung TY, Sun H, et al. (2011) Non-invasive prenatal assessment of trisomy 21 by multiplexed maternal plasma DNA sequencing: large scale validity study. BMJ.

31. Norton ME, Brar H, Weiss J, Karimi A, Laurent LC, et al. (2012) Non-Invasive Chromosomal Evaluation (NICE) Study: results of a multicenter prospective cohort study for detection of fetal trisomy 21 and trisomy 18. Am J Obstet Gynecol 207: e1-e8.

32. (2012) ACOG Committee opinion on NIPT (also supported by ISPD, the American National Society of Genetic Counselors and the Society for MaternalFetal Medicine), Number 545.

33. Osborne C, Hardisty E, Devers P, Kaiser-Rogers K, Hayden M, et al. (2013) False positive noninvasive prenatal testing results in a patient subsequently diagnosed with metastatic disease. Abstract presented at the American College of Medical Genetics and Genomics annual Clinical Genetics Meeting, March 2013, Phoenix, Arizona, USA. 